\title{
PENGEMBANGAN BAHAN AJAR KALKULUS INTEGRAL DENGAN PENDEKATAN APTITUDE TREATMENT INTERACTION (ATI) BERBANTU MACROMEDIA FLASH
}

\author{
Venty Meilasari ${ }^{1}$, Ratih Handayani ${ }^{2}$ \\ venty.meilasari@umko.ac.id
}

\section{Universitas Muhammadiyah Kotabumi}

\begin{abstract}
The difficulty of students in understanding the material in the integral calculus print book is one factor that makes student learning outcomes low. The difference in students' abilities is one of the considerations in developing process. This study aims to develop integral calculus teaching material using the aptitude treatment interaction (ATI) approach assisted by Macromedia flash. This research belongs to the development research. The instruments used in this study were questionnaires and tests. Indicators of the results of this study are teaching materials declared worthy of use and students who get optimal learning outcomes more than $75 \%$. The stages in the study consisted of ten stages that began with discovering potentials and problems to mass production. The results of the study showed that the integral calculus teaching material made was feasible to use. As many as $79 \%$ of students achieve optimal learning outcomes.
\end{abstract}

Keyword: Development, Teaching Materials, Integral Calculus, Aptitude Treatment Interaction, Macromedia Flash

\begin{abstract}
Abstrak: Kesulitan mahasiswa dalam memahami materi di buku cetak kalkulus integral menjadi salah satu factor yang menjadikan hasil belajar mahasiswa rendah. Perbedaan kemampuan mahasiswa menjadi salah satu pertimbangan dalam melakukan proses pengembangan. Penelitian ini bertujuan untuk menegmbangkan bahan ajar kalkulus integral dengan pendekatan aptitude treatment interaction (ATI) berbantu macromedia flash. Penelitian ini tergolong dalam penelitian pengembangan. Instrumen yang digunakan dalam penelitian ini adalah angket dan tes. Indikator capaian hasil penelitian ini adalah bahan ajar dinyatakan layak digunakan dan mahasiswa yang mendapatkan hasil belajar optimal lebih dari $75 \%$. Tahapan dalam penelitian terdiri dari sepuluh tahapan yang diawali dengan menemukan potensi dan masalah sampai pada produksi masal. Adapun hasil penelitian menunjukkan bahwa bahan ajar kalkulus integral yang dibuat telah layak digunakan. Sebanyak $79 \%$ mahasiswa mencapai hasil belajar yang optimal.
\end{abstract}

Kata kunci: Pengembangan, Bahan Ajar, Kalkulus Integral, Aptitude Treatment Interaction, Macromedia Flash

\section{PENDAHULUAN}

Kalkulus integral merupakan mata kuliah lanjutan dari kalkulus diferensial. Mata kuliah ini merupakan mata kuliah dasar bagi kalkulus integral lipat. Menguasai mata kuliah tersebut merupakan suatu keharusan bagi mahasiswa. Penguasaan materi ini salah satunya dapat dilihat dari kemampuan kognitifnya. Namun, kemampuan yang diharapkan ternyata tidak sesuai dengan kenyataan yang terjadi pada mahasiswa semester IV Program Studi Pendidikan Matematika STKIP Muhammadiyah Kotabumi. Hal ini terlihat dari 
sebaran nilai akhir mahasiswa pada mata kuliah ini, yaitu hanya 56,25\% mahasiswa yang mendapat nilai di atas cukup. Selebihnya, yaitu $12,5 \%$ mahasiswa mendapat nilai cukup, dan $31,25 \%$ mendapat nilai di bawah cukup. Untuk mencari penyebab dari rendahnya hasil tersebut maka dilakukan wawancara dengan semua mahasiswa semester IV Program Studi Pendidikan Matematika STKIP Muhammadiyah Kotabumi.

Berikut ini tanggapan 20 mahasiswa terhadap kondisi perkuliahan mata kuliah kalkulus integral.

1. Mahasiswa belum memiliki bahan ajar yang menarik.

2. Mahasiswa belum memiliki bahan ajar yang sesuai dengan kemampuan yang dimiliki.

3. Mahasiswa menganggap materi integral sulit diaplikasikan dalam kehidupan sehari-hari.

4. Mahasiswa bingung dengan materi pendahuluan luas yang menyebabkan kesulitan dalam memahami materi berikutnya.

5. Mahasiswa tidak terbiasa menggunakan teknologi dalam pembelajaran.

Berdasarkan tanggapan mahasiswa tersebut diperlukan suatu perbaikan pada proses pembelajaran sehingga mahasiswa dapat mengekplorasi kemampuan yang dimiliki. Beberapa hal yang dapat diperbaiki, yaitu bahan ajar serta pendekatan pembelajaran yang sesuai dengan tingkat kemampuan mahasiswa.

Bahan ajar merupakan salah satu komponen yang harus ada dalam pembelajaran. Trianto (2012:188) menyatakan bahwa bahan ajar adalah bahan atau material atau sumber belajar yang mengandung subtansi kemampuan tertentu yang akan dicapai oleh mahasiswa. Selanjutnya Pannen (dalam Sadjati, 2012:1.5) menyatakan bahwa bahan ajar adalah bahan atau materi pelajaran yang disusun secara sistematis, yang digunakan pengajar dan peserta didik dalam proses pembelajaran. Secara garis besar bahan ajar atau materi pembelajaran (instructional material) mencakup pengetahuan, keterampilan, dan sikap yang dipelajari mahasiswa dalam rangka mencapai kompetensi yang telah ditetapkan. Sadjati (2012:1.6) menambahkan bahwa bahan ajar bersifat unik dan spesifik. Artinya, suatu bahan ajar hanya dapat digunakan audiens tertentu dalam suatu proses pembelajaran tertentu. Untuk itu hendaknya dilakukan penyusunan bahan ajar oleh seorang dosen yang dapat digunakan dalam pembelajaran.

Langkah-langkah penyusunan bahan ajar menurut Ramdani (2012:51), yaitu: menganalisis secara teoretis bahan ajar; menganalisis secara empiris identifikasi permasalahan berkenaan dengan bahan ajar; mengembangkan prototipe bahan ajar; analisis teoretik bahan ajar; melakukan 
validasi bahan ajar oleh ahli; uji coba terbatas; dan penyempurnaan bahan ajar. Adapun fungsi penyusunan bahan ajar menurut Hernawan, Permasih, dan Dewi (2012:4), yaitu: sebagai pedoman bagi mahasiswa yang mengarahkan segala aktivitas dalam pembelajaran dan pedoman tentang apa yang harus dikuasai; pedoman bagi pendidik mengenai substansi yang harus diajarkan; dan sebagai alat evaluasi penguasaan pembelajaran.

Bahan ajar dapat dikelompokkan menjadi dua jenis. Menurut Hernawan, Permasih, dan Dewi (2012:5), Sadjati (2012:1.7) bahan ajar terdiri atas dua jenis, yaitu bahan ajar cetak dan bahan ajar noncetak. Bahan ajar cetak terdiri atas handout, buku pelajaran, modul, dan programed materials. Selanjutnya bahan ajar noncetak terdiri atas CD interaktif, TV, radio, realia, video, overhead transparencies $(O H T)$. Semakin berkembangnya IPTEK maka makin bermunculan bahan ajar noncetak, salah satunya adalah macromedia flash. Media ini akan membuat pembelajaran lebih menarik dan membuat mahasiswa lebih jelas dalam memahami teknik pengintegralan. Perpaduan antara buku ajar dengan macromedia flash ini cocok diterapkan pada mata kuliah Kalkulus Integral.

Pendekatan pembelajaran yang memperhatikan perbedaan kemampuan, yaitu Aptitude Treatment Interaction (ATI).
Melalui pendekatan ATI diasumsikan bahwa kemampuan kognitif akan optimal jika perlakuan dalam pembelajaran disesuaikan sedemikian rupa dengan perbedaan kemampuan siswa.

ATI menekankan pembelajaran yang berdasar pada perbedaan karakteristik mahasiswa. Menurut Siregar (2015:54) ATI merupakan suatu konsep atau model yang berisi sejumlah strategi pembelajaran (treatment) yang efektif digunakan untuk menangani mahasiswa tertentu sesuai dengan karakteristik kemampuannya. Hal ini didasari bahwa optimalisasi hasil belajar dapat dicapai dengan menyesuaikan antara pembelajaran (treatment) dengan kemampuan (aptitude) mahasiswa. Dazrullisa (2016:14) menambahkan bahwa keberhasilan penerapan ATI dapat dilihat dari kesesuaian antara perlakuan yang diterapkan dengan kemampuan mahasiswa.

Berdasarkan latar belakang masalah, maka dapat dirumuskan permasalahan "Bagaimana mengembangkan bahan ajar kalkulus integral dengan pendekatan ATI berbantu macromedia flash?". Berdasarkan rumusan masalah yang ada maka tujuan yang ingin dicapai, yaitu pengembangan bahan ajar kalkulus integral dengan pendekatan ATI berbantu macromedia flash.

Urgensi pengembangan bahan ajar kalkulus integral dengan pendekatan ATI berbantuan macromedia flash ini sangat bermanfaat bagi perkembangan kognitif 
seluruh mahasiswa. Pendekan ATI tidak hanya bermanfaat bagi mahasiswa yang kemampuan kognitifnya tinggi atau sedang, tetapi juga mahasiswa yang kemampuan kognitif rendah. Jika mahasiswa menguasai konsep integral dengan baik, mahasiswa dapat dengan mudah mengikuti mata kuliah lanjutan, yaitu mata kuliah integral lipat.

\section{METODE}

Penelitian ini termasuk dalam penelitian pengembangan. Terdapat beberapa tahapan atau langkah dalam penelitian jenis pengembangan. Adapun langkah penelitian pengembangan menurut Sugiyono (2013:409), yaitu sebagai berikut.

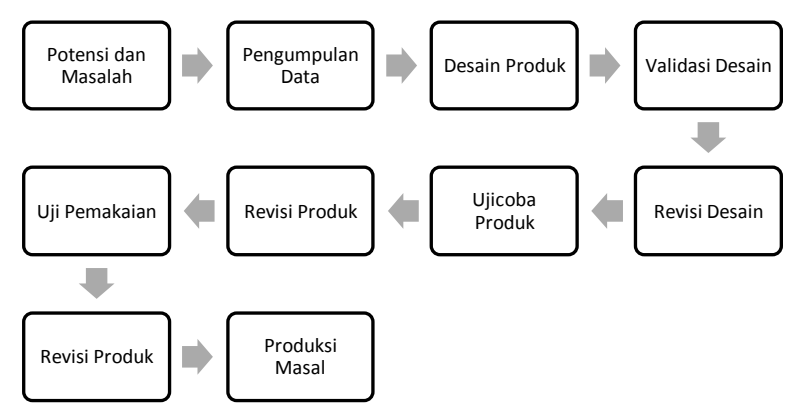

Gambar 1

Langkah Penelitian dan Pengembangan

Untuk mendapatkan data penelitian digunakan metode angket dan tes. Data dianalisis secara deskriptif kuantitatif, yaitu menghitung persentase skor bahan ajar yang dikembangkan

$$
\text { Persentase Skor }=\frac{\text { Jumlah Skor per indikator }}{\text { Jumlah Skor Maks.Indikator }} \times 100 \%
$$

Dari hasil perhitungan menggunakan rumus di atas, dihasilkan angka dalam bentuk persen. Klasifikasi skor tersebut kemudian ditafsir dengan kalimat bersifat kualitatif yang tercantum dalam tabel berikut ini.

\section{Kriteria Persentase Indikator Bahan Ajar Menurut Akbar (dalam Sibuea, 2015: 6)}

\begin{tabular}{|l|l|}
\hline \multicolumn{1}{|c|}{ Kriteria Validitas } & Tingkat Validitas \\
\hline Sangat valid, atau dapat digunakan tanpa revisi & $85 \%<\mathrm{X} \leq 100 \%$ \\
\hline $\begin{array}{l}\text { Cukup valid, atau dapat digunakan dengan revisi } \\
\text { kecil }\end{array}$ & $70 \%<\mathrm{X} \leq 85 \%$ \\
\hline $\begin{array}{l}\text { Kurang valid, disarankan tidak dipergunakan } \\
\text { karena perlu revisi besar }\end{array}$ & $50 \%<\mathrm{X} \leq 70 \%$ \\
\hline Tidak valid, atau tidak boleh dipergunakan & $0 \%<\mathrm{X} \leq 50 \%$ \\
\hline
\end{tabular}

Bahan ajar dikatakan baik dan layak digunakan jika dinyatakan valid oleh validator dengan rata rata kriteria minimal "Cukup Valid".

Selanjutnya Indikator capaian hasil penelitian ini adalah:

1. Bahan ajar kalkulus integral dengan pendekatan ATI berbantu macromedia flash dapat menunjang pembelajaran mahasiswa pada mata kuliah kalkulus integral.

2. Mahasiswa yang mendapatkan hasil belajar optimal dengan menggunakan bahan ajar dengan pendekatan ATI berbantu macromedia flash mencapai $\geq$ $75 \%$.

\section{HASIL DAN PEMBAHASAN}

Dalam penelitian ini terdapat beberapa tahapan yang dilalui. Diawali dengan menemukan masalah bahwa belum adanya bahan ajar kalkulus integral yang sesuai 
dengan karakteristik mahasiswa STKIP Muhammadiyah Kotabumi. Kemudian dilakukan penggalian informasi mendalam kepada siswa dengan menggunakan angket dan wawancara. Adapun tahapan selanjutnya diuraikan sebagai berikut.

\section{Desain Produk}

Pembuatan bahan ajar Kalkulus Integral sub-Teknik Pengintegralan dilakukan pada bulan April 2019. Diawali dengan diskusi tentang isi, teknik, gaya penyampaian yang akan dibuat pada bahan ajar. Setelah itu masing-maing anggota peneliti bekerja bahu-membahu demi terciptanya produk bahan ajar ini. Bahan ajar yang dibuat ada dua bentuk, yaitu bahan ajar berbentuk buku dan bahan ajar berbentuk media macromedia flash. Setelah materi buku selesai barulah dibuat bahan ajar berbentuk macromedia flash.

\section{Validasi dan Revisi Desain}

Agar mendapatkan bahan ajar yang layak digunakan, dilakukan validasi bahan ajar. Validasi terdiri atas validasi ahli materi, ahli bahasa, dan ahli desain. Saat melakukan validasi, validator memberikan penilaian berdasarkan angket yang disediakan dan memberikan saran secara verbal.

Pada penelitian ini untuk aspek materi divalidasi oleh Bapak Purna Bayu Nugroho, S.Pd., M.Pd. Beliau adalah salah satu dosen pendidikan matematika di STKIP Muhammadiyah Kotabumi. Penilaian bahan ajar dilakukan sebanyak tiga kali. Penilaian pertama, validator memberikan saran: tambahkan soal latihan; tambahkan pengantar di setiap teorema maupun kumpulan aturan pengintegralan; gunakan bahasa yang mengajak mahasiswa untuk fokus; dan tambahkan referensi. Pada validasi yang kedua, validator masih menekankan kepada penggunaan bahasa yang dapat mengajak mahasiswa untuk belajar secara mandiri. Bahan ajar ini dinyatakan layak digunakan tanpa revisi berarti pada validasi yang ketiga. Revisi bahan ajar tidak hanya didasarkan pada saran validator secara verbal, melainkan juga berdasarkan penilaian validasi bahan ajar. Berikut adalah penilaian validator ahli media.

Tabel 2

Hasil Validasi Ahli Materi

\begin{tabular}{|c|c|c|c|c|}
\hline \multirow{2}{*}{ No. } & \multirow{2}{*}{ Indikator Penilaian } & \multicolumn{3}{|c|}{ Penilaian ke- } \\
\hline & & 1 & 2 & 3 \\
\hline 1 & $\begin{array}{ll}\text { Kesesuaian } & \text { Materi } \\
\text { dengan RPS } & \\
\end{array}$ & 5 & 6 & 8 \\
\hline 2 & Keakuratan Materi & 14 & 15 & 16 \\
\hline 3 & Kemutakhiran Materi & 7 & 10 & 11 \\
\hline 4 & Teknik Penyajian & 6 & 7 & 7 \\
\hline 5 & $\begin{array}{l}\text { Kelengkapan } \\
\text { Penyajian }\end{array}$ & 12 & 15 & 16 \\
\hline 6 & $\begin{array}{l}\text { Penyajian } \\
\text { Pembelajaran }\end{array}$ & 6 & 7 & 10 \\
\hline 7 & $\begin{array}{l}\text { Keruntutan alur } \\
\text { Berpikir }\end{array}$ & 3 & 3 & 4 \\
\hline 8 & Karakteristik ATI & 5 & 6 & 8 \\
\hline 9 & Sistem Evaluasi & 8 & 10 & 10 \\
\hline & Jumlah & 66 & 79 & 90 \\
\hline & Rata-rata & 2,87 & 3,43 & 3,91 \\
\hline & Persentase $(\%)$ & 57,4 & 68,6 & 78,2 \\
\hline & Kriteria & $\begin{array}{c}\text { Kur } \\
\text { ang } \\
\text { vali } \\
\text { d }\end{array}$ & $\begin{array}{c}\text { Kur } \\
\text { ang } \\
\text { vali } \\
\text { d }\end{array}$ & $\begin{array}{c}\text { Cuk } \\
\text { up } \\
\text { vali } \\
\text { d }\end{array}$ \\
\hline
\end{tabular}


Aspek bahasa pada bahan ajar divalidasi oleh Dr. Sumarno, M.Pd. Beliau adalah salah satu dosen Pendidikan Bahasa dan Sastra Indonesia di STKIP Muhammadiyah Kotabumi. Penilaian aspek bahasa hanya dilakukan sekali. Saran yang disampaikan oleh validator: 1) Penulisan ejaan terutama penulisan huruf, kata, dan tanda baca perlu diperbaiki. 2) Penggunaan pronomina persona seperti kita sebaiknya dihindari. 3) Pengulangan kata dan istilah yang sama dalam satu kalimat sebaiknya dihindari. Adapun hasil butir penilaian validasi ahli bahasa dapat dilihat pada tabel berikut.

Tabel 3

Hasil Validasi Ahli Bahasa

\begin{tabular}{|l|lr|c|}
\hline No. & \multicolumn{2}{|l|}{ Indikator Penilaian } & Skor \\
\hline 1 & \multicolumn{2}{|l|}{ Lugas } & 14 \\
\hline 2 & \multicolumn{2}{|l|}{ Komunikatif } & 5 \\
\hline 3 & $\begin{array}{l}\text { Kesesuaian dengan } \\
\text { perkembangan } \\
\text { didik }\end{array}$ & 10 \\
\hline 4 & $\begin{array}{l}\text { Kesesuaian } \\
\text { kaidah } \\
\text { Indonesia }\end{array}$ & $\begin{array}{l}\text { dengan } \\
\text { bahasa }\end{array}$ & 16 \\
\hline & Jumlah & 45 \\
\hline & Rata-rata & 4,5 \\
\hline & Persentase & $90 \%$ \\
\hline \multicolumn{1}{r}{ Kriteria } & $\begin{array}{c}\text { Sangat } \\
\text { Valid }\end{array}$ \\
\hline
\end{tabular}

Validasi yang terakhir dilakukan adalah validasi kepada ahli media. Penilai untuk aspek media adalah Ibu Khusnul Khotimah, S.Kom., M.T.I. Beliau adalah salah satu dosen Teknik Informatika STKIP Muhammadiyah Kotabumi. Validasi ahli media dilakukan sebanyak 3 kali. Pada penilaian pertama, validator memberikan saran: cover buku masih terlihat monoton, kurang bermain dengan warna supaya lebih terlihat menarik; tambahkan informasi pada header dan catatan kaki nomor halaman; dan belum konsisten pada penempatan layout.

Pada penilaian kedua, validator memberikan komentar dan saran sebagai berikut. 1) Pemilihan warna pada tampilan cover untuk kombinasi kurang sesuai, setidaknya tambahkan sedikit gambar agar lebih menarik. 2) Tata letak pada penomoran halaman perlu diperhatikan konsistensinya. Pada penilaian yang ketiga, validator menyatakan bahwa bahan ajar sudah layak digunakan. Untuk hasil penilaian angket validasi ahli media dapat dilihat pada tabel berikut.

Tabel 4

Hasil Validasi Ahli Media

\begin{tabular}{|c|c|c|c|c|}
\hline \multirow{2}{*}{$\begin{array}{c}\text { No } \\
\text {. }\end{array}$} & \multirow{2}{*}{$\begin{array}{l}\text { Indikator } \\
\text { Penilaian }\end{array}$} & \multicolumn{3}{|c|}{ Penilaian ke- } \\
\hline & & 1 & 2 & 3 \\
\hline 1 & Teknikpenyajian & 7 & 8 & 8 \\
\hline 2 & $\begin{array}{l}\text { Kelayakan } \\
\text { Penyajian }\end{array}$ & 10 & 11 & 12 \\
\hline 3 & $\begin{array}{l}\text { Ukuran Bahan } \\
\text { Ajar }\end{array}$ & 4 & 4 & 4 \\
\hline 4 & Desain Cover & 18 & 20 & 24 \\
\hline 5 & $\begin{array}{l}\text { Desain Isi } \\
\text { Bahan Ajar }\end{array}$ & 14 & 16 & 16 \\
\hline 6 & $\begin{array}{l}\text { Media } \\
\text { Macromedia } \\
\text { Flash }\end{array}$ & 12 & 14 & 16 \\
\hline & Jumlah & 65 & 73 & 80 \\
\hline & Rata-rata & 2,95 & 3,32 & 3,64 \\
\hline & Persentase $(\%)$ & 59 & 66,4 & 72,8 \\
\hline & Kriteria & $\begin{array}{l}\text { Kuran } \\
\text { g valid }\end{array}$ & $\begin{array}{l}\text { Kuran } \\
\text { g valid }\end{array}$ & $\begin{array}{l}\text { Cuku } \\
\mathrm{p} \\
\text { valid }\end{array}$ \\
\hline
\end{tabular}




\section{Uji Coba Produk dan Revisi}

Uji coba produk dilaksanakan pada siswa semester VI prodi pendidikan matematika yang berjumlah 16 mahasiswa. Mahasiswa diminta untuk membaca draf buku kalkulus integral teknik pengintegralan dan media macromedia flash. Adapun rangkuman hasil angket respon mahasiswa yang terdiri atas 20 item, yaitu sebagai berikut.

Tabel 5

Rangkuman Hasil Respon Mahasiswa Ujicoba Produk

\begin{tabular}{|c|c|}
\hline No. Urut & Rata-rata skor \\
\hline 1 & 3,9 \\
\hline 2 & 4,2 \\
\hline 3 & 4,05 \\
\hline 4 & 3,95 \\
\hline 5 & 3,75 \\
\hline 6 & 3,65 \\
\hline 7 & 4,1 \\
\hline 8 & 3,85 \\
\hline 9 & 3,7 \\
\hline 10 & 4,15 \\
\hline 11 & 3,6 \\
\hline 12 & 3,9 \\
\hline 13 & 3,85 \\
\hline 14 & 4,2 \\
\hline 15 & 3,95 \\
\hline 16 & 3,85 \\
\hline Rata-rata keseluruhan & 3,92 \\
\hline Persentase (\%) & 78,4 \\
\hline Kriteria & Cukup valid \\
\hline
\end{tabular}

Berdasarkan Tabel 5, dapat disimpulkan bahwa hasil uji produk menyatakan bahwa bahan ajar memenuhi kriteria cukup valid untuk uji coba produk.

\section{Uji Pemakaian dan Revisi}

Uji pemakaian dilaksanakan pada mahasiswa semester IV Prodi Pendidikan
Matematika STKIP Muhammadiyah Kotabumi. Dalam uji coba ini diterapkan pendekatan Aptitude Treatment Interaction (ATI). Pembelajaran dengan pendekatan ATI diawali dengan pemberian aptitude testing. Tes ini berisi butir soal untuk mengetahui tingkat pemahaman awal mahasiswa tentang integral. Selain itu, hasil aptitude test merupakan dasar pembagian mahasiswa ke dalam kelompok tinggi sedang rendah. Pembagian kelompok tersebut didasarkan pada aturan: a) kelompok tinggi $(X>\bar{X}+0,5 s \quad$; b) kelompok sedang: $(\bar{X}-0,5 s \leq X \leq \bar{X}+0,5 s)$; dan c) kelompok rendah $(X<\bar{X}-0,5 s)$; dengan $X$ adalah skor mahasiswa, $\bar{X}$ adalah rerata skor keseluruhan, dan $s$ adalah simpangan baku. (Budiyono, 2015:13)

Aptitude test dilaksanakan pada tanggal 28 Mei 2019 yang diikuti sebanyak 42 mahasiswa. Penskoran tes dengan skala 0 100. Dari data hasil tes tersebut diketahui bahwa skor maksimal dan minimal masingmasing 98 dan 30. Rata-rata skor yang diperoleh adalah sebesar 57,45 dengan standar deviasi 17,85 . Selanjutnya dengan aturan yang telah disebutkan di atas, diperoleh pengelompokan sebagai berikut.

Tabel 6

Pembagian Kelompok Berdasarkan

\begin{tabular}{|c|c|c|}
\multicolumn{3}{c}{ Aptitude Test } \\
\hline Rentang Skor & Kelompok & $\begin{array}{c}\text { Banyaknya } \\
\text { Mahasiswa }\end{array}$ \\
\hline$X>66,38$ & Tinggi & 11 \\
\hline $\begin{array}{l}48,53 \leq X \\
\leq 66,38\end{array}$ & Sedang & 16 \\
\hline$X<48,53$ & Rendah & 15 \\
\hline
\end{tabular}


Setelah mahasiswa dibagi dalam tiga kelompok, selanjutnya diberikan perlakuan yang berbeda untuk masing-masing kelompok. Kelompok tinggi diberikan perlakuan berupa pembelajaran secara mandiri dengan menggunakan buku yang telah disiapkan. Kelompok sedang diberikan buku dan diberikan penjelasan atau presentasi materi dari dosen. Untuk kelompok rendah diberikan perlakuan yang sama dengan kelompok sedang, tetapi ditambah reteaching dengan bahan ajar berupa media macromedia flash.

Uji coba bahan ajar yang dilakukan berlangsung selama lima kali pertemuan. Selanjutnya dilakukan pemberian angket untuk mengetahui respon mahasiswa terhadap bahan ajar yang sedang diujicobakan. Adapun data hasil pengisian angket respon mahasiswa dapat dilihat pada tabel 7 berikut.

Tabel 7

Rangkuman Hasil Angket Mahasiswa Uji Pemakaian

\begin{tabular}{|c|c|c|c|}
\hline Kelompok & $\begin{array}{c}\text { Rerata } \\
\text { skor }\end{array}$ & $\begin{array}{c}\text { Persentase } \\
(\%)\end{array}$ & Kriteria \\
\hline Tinggi & 4,08 & 81,6 & \\
\hline Sedang & 4,13 & 82,6 & \\
\hline Rendah & 4,15 & 83 & \\
\hline $\begin{array}{c}\text { Rerata } \\
\text { Keseluruha } \\
\mathrm{n}\end{array}$ & 4,12 & 82,4 & $\begin{array}{c}\text { Cukup } \\
\text { valid }\end{array}$ \\
\hline
\end{tabular}

Berdasarkan Tabel 7 diketahui bahwa hasil angket respon mahasiswa mencapai rerata skor 4,12 dengan persentase $82,4 \%$. Berdasarkan aturan sebelumnya berarti bahan ajar mencapai kriteria cukup valid. Ini berarti bahan ajar sudah dapat digunakan dengan revisi kecil. Hal ini juga didukung dengan hasil validasi terhadap tiga validator pada bagian sebelumnya.

Selain pemberian angket, mahasiswa juga diberikan suatu tes. Hal ini bertujuan untuk melihat tingkat pemahaman mahasiswa setelah menggunakan bahan ajar. Berikut rangkuman hasil tes akhir.

Tabel 8

Rangkuman Hasil Tes Akhir Kalkulus Integral

\begin{tabular}{|c|c|c|}
\hline $\begin{array}{c}\text { Rentang } \\
\text { Skor }\end{array}$ & $\begin{array}{c}\text { Angka } \\
\text { Mutu }\end{array}$ & $\begin{array}{c}\text { Banyaknya } \\
\text { Mahasiswa }\end{array}$ \\
\hline $80-100$ & A & 12 \\
\hline $70-79$ & B & 12 \\
\hline $60-69$ & C & 9 \\
\hline $50-59$ & D & 9 \\
\hline $0-49$ & E & 0 \\
\hline \multicolumn{2}{|c}{ Jumlah } & 42 \\
\hline
\end{tabular}

Berdasarkan Tabel 8 diketahui bahwa semua mahasiswa telah lulus. Meskipun demikian, hanya 33 mahasiswa yang dinyatakan lulus dengan nilai minimal cukup. Hal ini telah memenuhi target yang ingin dicapai yaitu $75 \%$ atau lebih mahasiswa telah mencapai nilai cukup dikarenakan persentase yang dicapai sebesar 79\%. Itu artinya, bahan ajar teknik pengitegralan memberikan hasil belajar yang optimal.

\section{SIMPULAN}

Bahan ajar kalkulus integral dengan pendekatan ATI dan macromedia flash layak digunakan berdasarkan hasil penelitian. Bahan ajar yang dibuat telah memenuhi 
kriteria cukup valid berdasarkan penilaian validator dan hasil respon mahasiswa. Selanjutnya hasil belajar yang dicapai mahasiswa sudah mencapai indikator pencapaian yaitu $79 \%$. Artinya, dengan menggunakan bahan ajar yag disediakan, sebanyak $79 \%$ mahasiswa sudah mencapai hasil belajar kalkuluas integral yang optimal.

\section{DAFTAR RUJUKAN}

Budiyono. (2015). Pengantar Penilaian Hasil Belajar. Surakarta: Sebelas Maret University Press.

Dazrullisa. (2016). Model Pembelajaran Aptitude Treatment Interaction (ATI) dalam Meningkatkan Keativitas dan Motivasi. Matematika Jurnal. III(2). 12-21.

Hernawan, A.H., Permasih, dan Dewi, L. (2012). Pengembangan Bahan Ajar. Repositori Universitas Pendidikan Indonesia. Tersedia (http://file.upi.edu/Direktori/FIP/JUR._KURIKULUM_DAN_TEK._PENDIDIKAN/19 4601291981012-PERMASIH/PENGEMBANGAN BAHAN AJAR.pdf)

Ramdani, Y. (2012). Pengembangan Instrumen dan Bahan Ajar untuk Meningkatkan Kemampuan Komunikasi, Penalaran, dan Koneksi Matematis dalam Konsep Integral. Jurnal Penelitian Pendidikan. 13(1). 44-52.

Sadjati, I.M. (2012). Hakikat Bahan Ajar. Modul 1. Jakarta: Universitas Terbuka.

Sibuea, R. (2015). Pengembangan Bahan Ajar Matematika melalui Pendekatan Matematika Realistik Berbasis Kurikulum 2013 untuk Meningkatkan Kemampuan Komunikasi Matemattis siswa di Kelas VII SMP Tri Jaya Medan. Tersedia (https://www.academia.edu/8678852/Jurnal_Pengembangan_Bahan_Ajar_Model_4D)

Siregar, T.M. (2015). Penerapan Model Pembelajaran Aptitude Treatment Interaction (ATI) dalam Upaya Meningkat Hasil Belajar. Generasi Kampus. 8(2). 50 - 60.

Sugiyono. 2013. Metode Penelitian Pendidikan Pendekatan Kuantitatif, Kualitatif, dan R\&D. Bandung: Alfabeta.

Trianto. 2012. Mendesaian Model Pembelajaran Inovatif-Progresif. Jakarta: Kencana. 